\section{Exploring the Relationship with Financial Challenge, Inclusion, and Enterprising Women}

Kardan Journal of Economics and Management Sciences

3 (4) 89-115

(92020 Kardan University Kardan Publications Kabul, Afghanistan https://kardan.edu.af/Research/ Currentlssue.aspx?j=KJEMS

\author{
Mohammad Mushfiqul Haque Mukit \\ Nusrat Jahan Nabila \\ Assim Ibrahim Abdel-Razzaq
}

\begin{abstract}
The entrepreneurial process drives the economic activities significantly. In many developed countries including Bangladesh, female entrepreneurship is an increasingly rising phenomena. Women are an untapped source of economic progress, making up half of our population, and entrepreneurship is one way of mediating that growth by exploiting that tremendous pool of human resources. Cultural restrictions are one of the major factors boiling the development of women's entrepreneurship in Bangladesh. This study aimed to reduce the financial challenges, to establish the women's entrepreneurship in rural area, so that, contribute into the mainstreamed economy. Women's financial literacy is the key, but social consciousness must also play a major role in bridging this divide, and the paper is heading in that direction. To achieve the above objective, qualitative and quantitative methods have been used. Moreover, structured model questionnaire provided hundred random entrepreneurs in rural area to bring out the real insights of drawback and figure out how financial inclusions can contribute more in the informal economy. The results of this study suggest that complicated loans process, high-interest rates, absence of a life skills program, lack of financial freedom for women and property rights, entrepreneurial paradox, absence of collaterals, financial institutions negligence, mismanagement of loans, lack of interactions with local successful entrepreneur and imbalance of family and professional promise are the major barriers in accessing financial institutions in Bangladesh.
\end{abstract}

Keywords: Economy, Entrepreneur, Financial Inclusion, Informal Economy, Rural, Women.

JEL Classification Code: C54, E26, F43, O11, P52

Mr. Mohammad Mushfiqul Haque Mukit, Department of Economics, Jahangirnagar University, Dhaka, Bangladesh <mushfiq.mukit@gmail.com>

Ms. Nusrat Jahan Nabila, Department of Business Administration, University of Asia Pacific, Dhaka, Bangladesh <nushrat.15.nn@gmail.com>

Prof. Assim Ibrahim Abdel-Razzaq, Assistant Professor, Accounting \& Finance, Prince Mohammad Bin Fahd University, Al-Khobar, Kingdom of Saudi Arabia <aabdelrazzaq@pmu.edu.sa> 


\section{Introduction}

The world has recognized that women are a valuable human resource that can be used as a mediator of progress and growth. Women entrepreneurs not only generate new employment openings, but also offer numerous alternatives to management, corporate and market challenges for society. Many research studies find out that a shortage of funding is one of the key factors limiting the development of women's businesses in Bangladesh. For different factors including lack of collateral, refusal to consider household properties as collateral and unfavorable views of woman entrepreneurs by loan officers in the absence of credit scores and a proper business plan, women also have less chances than men to obtain access to credit. An inclusive financial system is important because it is recognized in development policy and priority all over the world. It helps well-organized allocation of productive resources and offers suitable financial services and can support slow the growth of informal sources of credit (Sarma, 2012). Access to finance has recognized to be the biggest impediment for small and medium-sized enterprises (SMEs) worldwide (Ghosh et al. 2017; Bamfo and Asiedu-Appiah 2012; Lader 1996). Small businesses, particularly in developing countries, have limited access to capital markets, in part due to the perceived higher agency costs for small businesses (Mohanty 2009; Biekpe 2004). An entrepreneur is someone who voluntarily engages in beginning a company just for personal use or is the owner/manager of a business less than 42 months old (Harding et al., 2006; Reynolds et al., 2002). In short informal entrepreneurship is described here as involving anyone who is actively interested in starting a business or is the owner/manager of a business less than 42 months old who is involved in the paid production and selling of goods and services that are legitimate in all respects, apart from the fact that they are unregistered or concealed from the goods and services state for purposes of revenue and/or advantage (Williams, 2006a, 2007a). In addition, it is now understood that much of this informal employment is performed on an own-account basis. For instance, some $70 \%$ of informal workers are self-employed in sub-Saharan Africa, $62 \%$ in North Africa, 60\% in Latin America and 59\% in Asia (ILO, 2002b).

One of the world's oldest and most prevalent type of inequality is gender inequality. It ignores the voices of women, devalues their jobs and makes the status of women inferior to that of men, from the household to the national and global level. Despite some significant success in improving this situation in recent years, women have not attained economic equality with men in any region, and women are much more likely to live in poverty than men. Small businesses help to provide jobs, reduce migration from 
rural-urban country to city, and ensure efficient use of resources (Collingridge, 2013). Low education prevents women from paid employment in the formal sector, but as active agents with the intention of changing their situation, these women become innovative and start small businesses, including small ones. The Global Entrepreneurship Monitor (GEM) (2010) and Kelley et al. (2011) indicate that growing the figure of women micro-entrepreneurs involved in opening new businesses and expanding current businesses which is crucial for a country's long-term economic growth. Technological advancement in communication influences rural life along with urban life and people becoming internet service dependent and tech-savvy, the growth of internet banking keeps positive contributions (Mukit \& Islam, 2018). Now the time for trade, commerce, and all stakeholders should come forward to work for financial inclusions and mitigating the losses and costs, as low as possible (Islam \& Mukit, 2019). Female disparity in the economy costs $\$ 9$ trillion a year for women in developed countries, an amount that would not only give women new purchasing power and support their families and societies, but would also provide the economy as a whole with a huge boost. Countries with higher levels of gender equality appear to have higher levels of wealth, and data from a range of regions and countries suggests that narrowing the gap contributes to poverty reduction (Oxfam, 2020). Previous research has established that securing loans at lower interest rates is a convenient process that could stimulate the economic growth of rural areas, where many woman entrepreneurs could start and operate their SMEs even more quickly and effectively. Several studies have conducted in different geographical locations, but very few research-led on financial inclusions and rural women's entrepreneurs' constraints. Particularly, this study emphasizes financial obstacles cases and the way how women become powerful human capital can as financially. Financial inclusion increases risky behavior. If stakeholders have a trustworthy place to keep money and easy access to get a loan, they easily tackle the unwanted risk. To understand the financial resilience of people around the world, we need a country-specific data set to analyze the most important integrated factors under the local circumstances. Therefore, promoting women's access to quality and decent jobs and enhancing their livelihoods is necessary for fulfilling the rights of women, mitigating poverty and achieving wider growth objectives.

\section{Literature Review}

\subsection{Financial Inclusion Status in Bangladesh}

Financial inclusion refers to the access and use of households and business institutions of structured financial services. Policymakers see it as 
an approach to raising the wages of individuals, reducing poverty and driving global growth (IMF, 2015). Consideration of financial inclusion may also be translated as needing to access and use financial resources which meet the user's needs (BIS, 2015). Proactive regulatory policies and developed financial literacy proficiency are the primary drivers for the positive effect of financial inclusion in Bangladesh. Exact data dependent on household-level data show that the force of financial proficiency in Bangladesh is moderate and positively affects comprehensive financing. These results certify more importance on increasing financial literacy for access to finance and informed investment decisions (Khalily, 2016). It analyzed financial inclusion and its position in Bangladesh and concluded that financial inclusion plays an important role in the geographical and demographic spread of banking services. Financial inclusion was presented by Rahman (2009) in terms of the number of bank accounts, members of the MFI, cooperatives, and the adult population ratio. This study exposes significant gaps and suggests the measures needed in Bangladesh for greater financial inclusion. However, in societies with low financial inclusion, many people experience financial difficulties due to the unavailability of financial services. We know that more than 2.5 billion people worldwide are denied access to financial services (GPFI, 2011), which means that around $30 \%$ of the world's population is financially excluded and has financial stability problems. In Bangladesh, access to all kinds of savings exceeds $70 \%$ in the administrative areas of the country: Khulna, Barisal, Rangpur, and Rajshahi. However, the rates for families accessing a bank savings account are the highest in Sylhet and Khulna, and other departments do not have significant access rates to a bank savings account. New concepts have been introduced in Bangladesh's financial sector in recent years, with ATMs, credit cards, debit cards, mobile banking, and ten Taka (Bangladeshi Currency) ( $\$ 0.12$ ) accounts being used more and more. Among these services, mobile banking has seen a surge in popularity. The customer does not have to go to a bank branch and transactions can be made from their own mobile bank account or from someone else's bank account. Therefore, it is convenient for poor and wealthy customers (Khalily M. A., 2014).

\subsection{Small and Medium-Sized Enterprises (SMES) in Bangladesh}

The Asian Development Bank revealed in 2016 that Bangladesh is one of the most significant countries in the world, with $99 \%$ of business organizations being SMEs (ADB, 2016). Notwithstanding, the figure of SMEs in Bangladesh has expanded each year and there are currently more than 79 million SMEs in Bangladesh. The financial capital of SMEs and the number of workers in Bangladesh vary from those in Table 1. 
Table 1: The financial capital of SMEs and worker in Bangladesh

\begin{tabular}{|c|c|c|c|}
\hline $\begin{array}{l}\text { Size of } \\
\text { Enterprise }\end{array}$ & Industry & $\begin{array}{l}\text { Required Capital } \\
\text { (USD \$) }\end{array}$ & Number of Workers \\
\hline \multirow{2}{*}{ Small } & \multirow{3}{*}{ 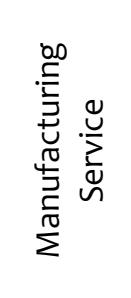 } & $\begin{array}{l}88,384.50 \text { USD to } \\
1,76,769.0 \text { USD }\end{array}$ & 31 to 20 \\
\hline & & $\begin{array}{l}1,76,769 \text { USD to } \\
6,48,1530.00 \text { USD }\end{array}$ & 16 to 50 \\
\hline Medium & & $\begin{array}{l}2,35,692.00 \text { USD } \\
\text { to } 41,24,610.00 \\
\text { USD }\end{array}$ & $\begin{array}{l}121 \text { to } 300 \text { but for labor intensive } \\
\text { industries not more than } 1,00051\end{array}$ \\
\hline
\end{tabular}

Source: National Industrial Policy (2016) as cited in (Abdin, 2017)

The future growth of Bangladesh, taking into account small and medium-sized enterprises (SMEs), is therefore especially relevant for women entrepreneurs, according to the Bangladesh Bank (2018) and the World Bank (2019), since it is funded by diverse interest groups, such as governments and financial institutions. Women entrepreneurs, however, face several challenges found in some prior research, and these are addressed in the next section.

The contribution of micro, small and medium enterprises (MSMEs) is very difficult to measure, in particular by measuring the contribution of women in the absence of available data. Alam and Miyagi (2004) stated that the contribution of MSMEs was Tk. 741 billion, equivalent to 20 to 25 percent of gross domestic product (US\$10.15 billion) (GDP). Around 40 percent of the population (above 15 years of age) are working in both rural and urban areas in this sector. Estimates from the International Consulting Group (ICG) detailed 2003 survey. For 6 million companies, the cumulative number of MSMEs. The business employs 31 million people and accounts for about $25 \%$ of GDP (Alam and Ullah, 2006). About 75 percent of these companies are based in rural areas, reflecting the high proportion of the rural population. Ninety percent of all MSMEs have less than 10 jobs, and between 51 and 100, just 2 percent.

Table 2: Summary of micro, small and medium enterprise definition in Bangladesh

\begin{tabular}{llll}
\hline \multirow{2}{*}{ Microenterprise } & $\begin{array}{l}\text { Trade, service and operation, } \\
\text { development, transport, } \\
\text { infrastructure and } \\
\text { construction, etc. }\end{array}$ & $\begin{array}{l}\text { Family } \\
\text { members } \\
\text { mostly. }\end{array}$ & $\begin{array}{l}\text { Less than } \\
\$ 11,795\end{array}$ \\
\hline \multirow{3}{*}{ Small enterprise } & $\begin{array}{l}\text { Trade, service and operation, } \\
\text { development, transport, } \\
\text { infrastructure and } \\
\text { construction, etc. }\end{array}$ & Less than 25 & Less than \\
workers & $\$ 17,692$ \\
\hline
\end{tabular}




\begin{tabular}{llll} 
& $\begin{array}{l}\text { Trade, service and operation, } \\
\text { Medium enterprise } \\
\text { development, transport, }\end{array}$ & 25 to 100 & Less than \\
infrastructure and & workers & \$17,692 to \$ \\
construction, etc. & & 117,942 \\
\hline
\end{tabular}

Source: Bangladesh Bank (2010); MIFA (2009)

\subsection{Women Entrepreneurs Faces Constrain}

Research conducted by (Jahed, et. al. 2011), also found that women entrepreneurs in Bangladesh face various problems, such as gender issues, lack of institutional support, lack of financial and social capital support, etc. Recent research has also revealed that women who participate as entrepreneurs are not welcome in many rural and urban areas (Afrin, Islam, \& Ahmed, 2010). As indicated by Riyad et al. (2010), infrastructure is one of the main obstacles for entrepreneurs in Bangladesh to start and continue the business. This is likewise demonstrated in recent research by Ghosh et al. (2017) affirmed. In addition, Nawaz (2012) and Ghosh et al. (2017) have implemented complex institutional lending processes as another barrier for women entrepreneurs. They found that loaning processes in banks and other financial organizations were structured so that women entrepreneurs did not have easier access to finance. In this regard, lack of professionalism, poor training, and lack of security knowledge among bank managers have been identified as deterrents for women entrepreneurs to acquire credit (Nawaz, (2012)). Furthermore, the lack of marketing opportunities, the lack of raw materials, insufficient knowledge and experience, difficulties in account management, precarious movements, male-dominated social structures, delays in the process of Credit, high-interest rates, and harassment of law enforcement are also barriers for women and even other entrepreneurs in Bangladesh (Chowdhury, 2013, cited in Ghosh et al., 2017). Lack of access to institutional finance, the consumer market for SME products, and unavailability of a formal entrepreneurship development program in Bangladesh. It's considering SMEs are the main obstacle to new business and existing company's market growth (Chowdhury et al. (2013)). The Dhaka Chamber of Commerce and Industry (DCCI) recorded the demand side (lack of security, limited business experience, and information, etc.) and supply (terms and conditions, lack of access to start-up financing, availability of funds for) in its working document on the economic policy of 2004. Banks, etc.) As problems of access to financing for SMEs in Bangladesh. For SMEs, the Registering process is complicated in the respective agencies is another obstacle for men and women to obtain loan. Financial organization's first requirement, it has to be registered SMEs. In addition, Ghosh et al. (2017) recognized that the lack of business plans, the small size of the business, and the smaller start-up capital creates a negative 
impression on bank managers whether women entrepreneurs would continue to do business or not. Rahman et al. (2013) similarly found that the loan process in banks was not flexible and direct for new or existing entrepreneurs, especially women entrepreneurs, which additionally makes hurdles to gaining credit from banks. This is largely similar to the perspective of emerging countries around the world (Esayas and Tolossa, 2015).

\section{Table 3: Several Authors Study \&}

\section{Outcomes}

\begin{tabular}{|c|c|c|c|c|c|}
\hline$\dot{\bar{n}}$ & 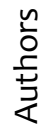 & Title & Objective & Study Area & Result \\
\hline- & 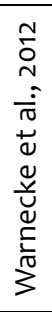 & $\begin{array}{c}\text { Female } \\
\text { Entrepreneur } \\
\text { ship in China: } \\
\text { Opportunity } \\
\text { or Necessity- } \\
\text { Based? }\end{array}$ & $\begin{array}{l}\text { This paper examines } \\
\text { that different classes of } \\
\text { entrepreneur's faces } \\
\text { various hindrances and } \\
\text { that women need aid to } \\
\text { limit gender gap in } \\
\text { entrepreneurship }\end{array}$ & $\begin{array}{l}\text { Concentrated on policies } \\
\text { and experiment has given } \\
\text { two arrangement } \\
\text { destinations: } \\
\text { to reduce need-based } \\
\text { entrepreneurship and to } \\
\text { promote opportunity-based } \\
\text { entrepreneurship. } \\
\text { Method: Qualitative }\end{array}$ & $\begin{array}{l}\text { Approaches must be } \\
\text { carefully executed, open } \\
\text { doors based business } \\
\text { enterprise extended, ladies' } \\
\text { privileges ensured and sex } \\
\text { fairness built up for financial } \\
\text { turn of events. }\end{array}$ \\
\hline$N$ & 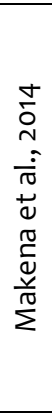 & $\begin{array}{l}\text { Challenging } \\
\text { and facing } \\
\text { women } \\
\text { entrepreneur } \\
\text { s in accessing } \\
\text { business } \\
\text { finance in } \\
\text { Keneya: case } \\
\text { of Ruiru } \\
\text { Township, } \\
\text { Kiambu } \\
\text { Country }\end{array}$ & $\begin{array}{l}\text { Distinguish the effect } \\
\text { of social standards, } \\
\text { family responsibilities, } \\
\text { gender-discriminating } \\
\text { factors, lacking data, } \\
\text { and breaking point the } \\
\text { security for access to } \\
\text { credit. }\end{array}$ & $\begin{array}{l}\text { The device was utilized to } \\
\text { explain complex choices } \\
\text { among qualitative and } \\
\text { quantitative data, while } \\
\text { keeping up the fulfillment, } \\
\text { precision and consistency } \\
\text { of the instruments. In this } \\
\text { study, frequencies, rates, } \\
\text { and chi-square techniques } \\
\text { were applied. } \\
\text { Method: Quantitative; } \\
\text { Population size: } 1443\end{array}$ & $\begin{array}{l}\text { Financial institutions need to } \\
\text { provide a special package } \\
\text { and invest in the education } \\
\text { sector to change the } \\
\text { negativity and to build trust } \\
\text { first, which helps to } \\
\text { recognize and strengthen } \\
\text { the business. Marital status is } \\
\text { another disadvantage of } \\
\text { being an entrepreneur. }\end{array}$ \\
\hline$m$ & 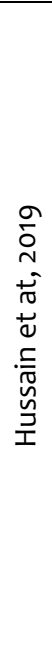 & $\begin{array}{c}\text { Does } \\
\text { financial } \\
\text { inclusion } \\
\text { increase } \\
\text { financial } \\
\text { resilience? } \\
\text { Evidence } \\
\text { from } \\
\text { Bangladesh }\end{array}$ & $\begin{array}{l}\text { This study explores the } \\
\text { impact of financial } \\
\text { inclusion on financial } \\
\text { resilience in Bangladesh }\end{array}$ & $\begin{array}{l}\text { In this work, two known } \\
\text { statistical techniques, the } \\
\text { chi-square test, multiple } \\
\text { binary logistics model } \\
\text { developed and logistic } \\
\text { regression analysis, were } \\
\text { used to test the } \\
\text { hypotheses. The chi-square } \\
\text { test is used to consider the } \\
\text { financial resilience variable } \\
\text { as a four- and two-step } \\
\text { factor. These two tests } \\
\text { show univariate and } \\
\text { multivariate relationships } \\
\text { between the factors } \\
\text { considered for financial } \\
\text { resilience. } \\
\text { Method: Quantitative } \\
\text { Interview Size: } 1000\end{array}$ & $\begin{array}{l}\text { This study strongly expect } \\
\text { that numerous hindrances } \\
\text { can be removed by } \\
\text { presenting better strategies. } \\
\text { There is a significant } \\
\text { relationship between gender } \\
\text { and financial resilience when } \\
\text { men enjoy better financial } \\
\text { resilience than women. } \\
\text { These results are useful for } \\
\text { policy ways to improve } \\
\text { financial inclusion through } \\
\text { targeted programming for } \\
\text { rural areas, low-income, } \\
\text { female-headed households } \\
\text { and poorly educated people. }\end{array}$ \\
\hline
\end{tabular}




\begin{tabular}{|c|c|c|c|c|c|}
\hline$\sigma$ & 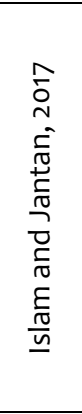 & $\begin{array}{l}\text { The Glass } \\
\text { Ceiling: } \\
\text { Career } \\
\text { Barriers for } \\
\text { Female } \\
\text { Employees in } \\
\text { the Ready } \\
\text { Made } \\
\text { Garments } \\
\text { (RMG) } \\
\text { Industry of } \\
\text { Bangladesh } \\
\end{array}$ & $\begin{array}{l}\text { The study aims to } \\
\text { identify the problems } \\
\text { with the glass ceiling } \\
\text { and the career } \\
\text { obstacles for female } \\
\text { employees in accessing } \\
\text { management positions } \\
\text { in Readymade } \\
\text { Garments (RMG) } \\
\text { organizations in } \\
\text { Bangladesh. }\end{array}$ & $\begin{array}{l}\text { The researchers chose a } \\
\text { qualitative approach for } \\
\text { this exploratory study } \\
\text { based on semi-structured } \\
\text { interviews with } 10 \\
\text { employees from } 5 \text { clothing } \\
\text { factories in Dhaka. } \\
\text { Method: Qualitative } \\
\text { Interview Size: } 10\end{array}$ & $\begin{array}{l}\text { This paper suggested to the } \\
\text { organizations higher } \\
\text { authority and govt. officials } \\
\text { to set rules and regulations } \\
\text { for the advancement of } \\
\text { female into the leadership } \\
\text { positions. Additionally, } \\
\text { significant improvement has } \\
\text { seen amidst the partners and } \\
\text { family which imbue to take } \\
\text { leadership roles in the } \\
\text { workplaces. }\end{array}$ \\
\hline in & 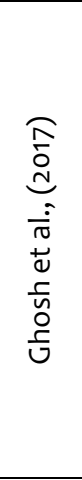 & $\begin{array}{c}\text { Factors } \\
\text { hindering } \\
\text { women } \\
\text { entrepreneur } \\
\text { s' access to } \\
\text { institutional } \\
\text { finance-an } \\
\text { empirical } \\
\text { study. } \\
\text { Journal of } \\
\text { Small } \\
\text { Business \& } \\
\text { Entrepreneur } \\
\text { ship. }\end{array}$ & $\begin{array}{l}\text { This study showed that } \\
\text { collateral disputes and } \\
\text { lengthy processes, } \\
\text { mistrust, prejudice and } \\
\text { conservative attitudes } \\
\text { among employees, as } \\
\text { well as the complexity } \\
\text { of loan processing, } \\
\text { restrict women } \\
\text { entrepreneurs' access } \\
\text { to institutional finance. }\end{array}$ & $\begin{array}{l}\text { This study is an empirical } \\
\text { study based on primary } \\
\text { data. Quantitative and } \\
\text { qualitative approaches have } \\
\text { been used here. The } \\
\text { reliability test, Kaiser } \\
\text { Meyer-Olkin (KMO) and } \\
\text { Bartletts sphericity test } \\
\text { were performed to test our } \\
\text { data set. } \\
\text { Method: Quantitative \& } \\
\text { Qualitative have been } \\
\text { conducted to test our data } \\
\text { set. }\end{array}$ & $\begin{array}{l}\text { Finally, found collateral } \\
\text { disputes and lengthy loan } \\
\text { payments, conservative } \\
\text { attitudes, and distrust } \\
\text { Financial institution prejudice } \\
\text { and the complexity of loan } \\
\text { processing are key problems } \\
\text { for women entrepreneurs to } \\
\text { receive financial support } \\
\text { from financial institutions. }\end{array}$ \\
\hline ๑ & 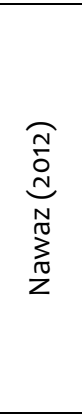 & $\begin{array}{l}\text { Problems of } \\
\text { Woman } \\
\text { Entrepreneur } \\
\text { ship } \\
\text { Developmen } \\
\text { t in } \\
\text { Bangladesh: } \\
\text { A Case Study } \\
\text { of RAKUB. }\end{array}$ & $\begin{array}{l}\text { Both primary and } \\
\text { secondary data used } \\
\text { for this study analysis. } \\
\text { The study highlights the } \\
\text { complicated credit } \\
\text { processing system, } \\
\text { small amount of capital } \\
\text { and high interest } \\
\text { expenses, which pose a } \\
\text { social and economic } \\
\text { challenge for } \\
\text { stakeholders. }\end{array}$ & $\begin{array}{l}\text { Semi-structured in-depth } \\
\text { interview of employees and } \\
\text { borrowers. The focus group } \\
\text { discussion (FGD) } \\
\text { considered beneficiary for } \\
\text { both participants for } \\
\text { qualitative research. Each } \\
\text { group consisted of 6-10 } \\
\text { participants. } \\
\text { Method: Qualitative }\end{array}$ & $\begin{array}{l}\text { The credit sanctioning } \\
\text { process requires some } \\
\text { changes, increases the } \\
\text { workforce, and provides } \\
\text { logistical support and needs- } \\
\text { based training. In addition, } \\
\text { the sale of the loan must be } \\
\text { facilitated within the time } \\
\text { limit. }\end{array}$ \\
\hline$\lambda$ & 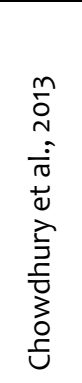 & $\begin{array}{c}\text { Success } \\
\text { Factors of } \\
\text { Entrepreneur } \\
\text { s of Small } \\
\text { and Medium } \\
\text { Sized } \\
\text { Enterprises: } \\
\text { Evidence } \\
\text { from } \\
\text { Bangladesh. }\end{array}$ & $\begin{array}{l}\text { Environmental factors } \\
\text { and demographic } \\
\text { characteristics have } \\
\text { considered the main } \\
\text { obstacle to the success } \\
\text { of SMEs in Bangladesh. }\end{array}$ & $\begin{array}{l}\text { For analysis of data, } \\
\text { descriptive statistics, } \\
\text { correlation and regression } \\
\text { analyzes, validity and } \\
\text { reliability of the instrument } \\
\text { test and the widely used } \\
\text { bivariate correlation } \\
\text { technique by Pearson R. } \\
\text { Method: Quantitative } \\
\text { Size: } 80\end{array}$ & $\begin{array}{c}\text { A new entrepreneurial class } \\
\text { has emerged in the country, } \\
\text { The challenge of working in a } \\
\text { competitive, complex } \\
\text { economic and business } \\
\text { environment. A favorable } \\
\text { political and economic } \\
\text { climate is a prerequisite for } \\
\text { the development of a } \\
\text { company in a country in the } \\
\text { world. }\end{array}$ \\
\hline$\infty$ & 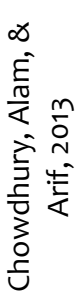 & $\begin{array}{l}\text { Factors } \\
\text { affecting } \\
\text { access to } \\
\text { finance of } \\
\text { small and } \\
\text { medium } \\
\text { enterprises } \\
\text { (SMEs) of } \\
\text { Bangladesh. }\end{array}$ & $\begin{array}{l}\text { This study looks at the } \\
\text { problems that are } \\
\text { preventing SMEs in } \\
\text { Bangladesh from } \\
\text { raising funds from } \\
\text { financial institutions. }\end{array}$ & $\begin{array}{l}\text { A five point Likert scale was } \\
\text { used to measure that } \\
\text { Variables and questioned } \\
\text { the sample populations. } \\
\text { Method: Qualitative } \\
\text { Size: } 86\end{array}$ & $\begin{array}{l}\text { The high interest rate, the } \\
\text { lack of security of the } \\
\text { collateral, the short } \\
\text { reimbursement deadlines. }\end{array}$ \\
\hline
\end{tabular}




\begin{tabular}{|c|c|c|c|c|c|}
\hline$a$ & 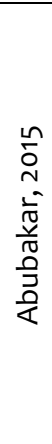 & $\begin{array}{l}\text { Entrepreneur } \\
\text { ship } \\
\text { development } \\
\text { and financial } \\
\text { literacy in } \\
\text { Africa. } \\
\text { World } \\
\text { Journal of } \\
\text { Entrepreneur } \\
\text { ship. }\end{array}$ & $\begin{array}{l}\text { The research exam } \\
\text { relates to financial } \\
\text { literacy, which affects } \\
\text { household behavior } \\
\text { and the gender gap in } \\
\text { relation to financial } \\
\text { decisions in financial } \\
\text { literacy and impact on } \\
\text { society for } \\
\text { entrepreneurship in } \\
\text { Africa. }\end{array}$ & $\begin{array}{l}\text { The surveys focused on } \\
\text { areas such as a lack of } \\
\text { awareness of certain basic } \\
\text { financial products, financial } \\
\text { literacy, and the need to } \\
\text { improve financial access or } \\
\text { increase business } \\
\text { productivity. They also } \\
\text { recognize the vulnerable } \\
\text { populations and Prioritize } \\
\text { supply side failures. } \\
\text { Method: Quantitative \& } \\
\text { Qualitative }\end{array}$ & $\begin{array}{l}\text { The surveys focused on areas } \\
\text { such as a lack of awareness } \\
\text { of certain basic financial } \\
\text { products, financial literacy, } \\
\text { and the need to improve } \\
\text { financial access or increase } \\
\text { business productivity, } \\
\text { moreover, recognize the } \\
\text { vulnerable populations and } \\
\text { Prioritize supply side failures. }\end{array}$ \\
\hline 음 & 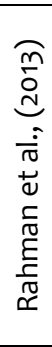 & $\begin{array}{l}\text { The Role of } \\
\text { Banks in } \\
\text { Promoting } \\
\text { Women } \\
\text { Entrepreneur } \\
\text { ship in } \\
\text { Bangladesh. } \\
\text { Dhaka: BB- } \\
\text { BARD. }\end{array}$ & $\begin{array}{l}\text { This survey shows the } \\
\text { gender differences in } \\
\text { various issues such as } \\
\text { appropriateness of the } \\
\text { loan amount, interest } \\
\text { rate, formalities for } \\
\text { loan processing and } \\
\text { microfinance to } \\
\text { eradicate poverty. }\end{array}$ & $\begin{array}{l}\text { Descriptive and inferential } \\
\text { statistical tools applied such } \\
\text { as the mean, the standard } \\
\text { deviation (SD), the mode, } \\
\text { the independent t-test, the } \\
\text { chi-square test and the } \\
\text { ordered logistic regression. } \\
\text { Method: Quantitative \& } \\
\text { Qualitative } \\
\text { Size:100 }\end{array}$ & $\begin{array}{l}\text { Women are less successful in } \\
\text { terms of gender bias and } \\
\text { microfinance. Microfinance is } \\
\text { still involved in debates and } \\
\text { biases, and this is a more } \\
\text { motivating factor. Such as } \\
\text { mortgage free loan, the } \\
\text { appropriate rate system, less } \\
\text { formalities for taking out } \\
\text { loans, etc. }\end{array}$ \\
\hline$\mp$ & 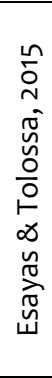 & $\begin{array}{l}\text { Women's } \\
\text { Economic } \\
\text { Empowerme } \\
\text { nt, Obstacles } \\
\text { for Success: } \\
\text { Experiences } \\
\text { from } \\
\text { Southern } \\
\text { Ethiopia. }\end{array}$ & $\begin{array}{l}\text { How microfinance has } \\
\text { empowered women, } \\
\text { participation in the } \\
\text { program in southern } \\
\text { Ethiopia has only } \\
\text { influenced a few } \\
\text { factors in the credit } \\
\text { assessment. }\end{array}$ & $\begin{array}{c}\text { In this report, cross- } \\
\text { sectional design was used } \\
\text { to obtain quantitative data } \\
\text { from women benefiting } \\
\text { from microfinance. } \\
\text { Method: Qualitative \& } \\
\text { Quantitative } \\
\text { Size:100 }\end{array}$ & $\begin{array}{l}\text { Institutional factors, } \\
\text { bureaucracy, are one of the } \\
\text { main reasons for influencing } \\
\text { the participation of women } \\
\text { in the micro-finance program } \\
\text { in the study area. An } \\
\text { incorporated evidence-based } \\
\text { program is assigned to } \\
\text { stakeholders and has a social } \\
\text { and financial impact on the } \\
\text { empowerment of women. }\end{array}$ \\
\hline
\end{tabular}

\section{Source: Author Adopted}

\subsection{Research Questions}

a) Why women are facing challenges in the financial economy?

b) How traditional banking constraints against flourishing women and the economy in rural Bangladesh?

c) How banking collaterals and instruments are the main complications to falling behind in the economy in rural Bangladesh?

d) What are the key indicators entangled in suppressing rural women's development and financial equality in Bangladesh?

\subsubsection{Research Design, Data Collection \& Methodology}

Demographic characteristics of the respondents: In this survey 100 respondents, $60 \%$ were female and $40 \%$ male. This selection was made deliberately to determine the views of male entrepreneurs on the restrictions on access to funds to manage their businesses compared to their female counterparts. In terms of age distribution, no particular age group was used to select both small and female entrepreneurs. The inquiry revealed that the majority (90\%) of the women participants received their primary investment from parents, mainly from their husbands or partners. 
Indeed, the majority of these women have been rejected by traditional banks as well as by microfinance institutions (MFls) for lack of guarantees to access credit. Most men (45\%) received their start-up capital for their companies from microfinance institutions (MFIs).

Table 3: The demographic characteristics of participants

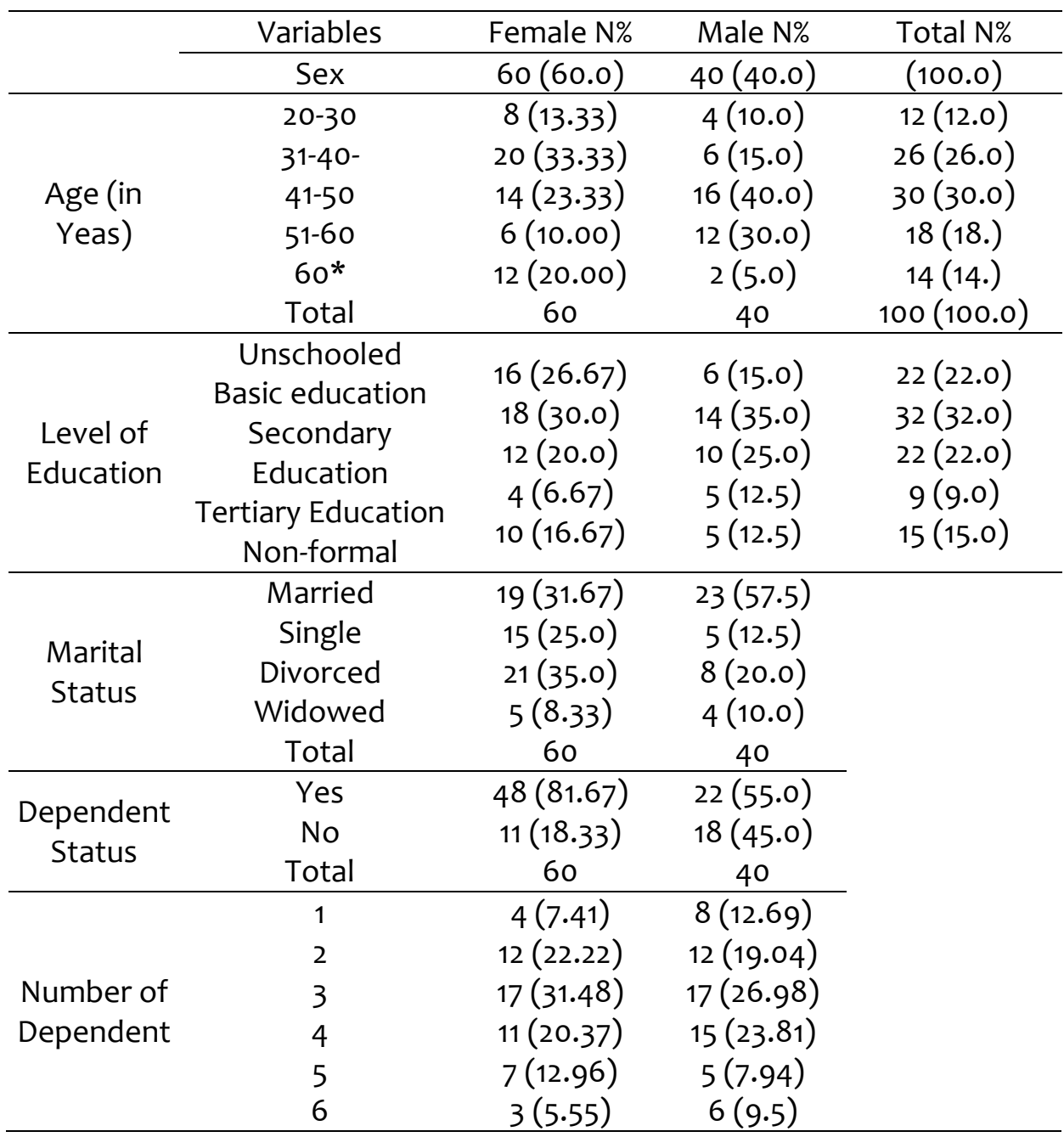

Source: Author Adopted field survey, Jan-March, 2020

This demographic characteristics of participants will help for our study significantly.

Table 4. Initial capital investment collected for SME business in Bangladesh

\begin{tabular}{llll}
\hline Sources & Female N\% & Male N\% & Total N\% \\
\hline Relatives & $31(51.67)$ & $11(27.5)$ & $42(42.0)$ \\
Friends & $8(13.33)$ & $5(12.5)$ & $13(.23)$ \\
Bank & $7(11.67)$ & $9(22.5)$ & $16(16.0)$ \\
Financial & $6(10.0)$ & $7(17.5)$ & $13(13.0)$ \\
Institutions & & & \\
\hline
\end{tabular}




\begin{tabular}{llll}
\hline NGO/INGO & $8(13.33)$ & $8(20.0)$ & $16(16.0)$ \\
\hline Total & 60 & 40 & 100 \\
\hline
\end{tabular}

Source: Author adopted, field survey, Jan-March, 2020

In this research study employed primary data. In order to achieve our research objective, a mixed research design considered where the quantitative and qualitative methods applied. This study is divided into two parts. Firstly, data were collected and analyzed from women entrepreneurs based on a quantitative approach to detect factors that prevent them from raising funds from commercial banks. Secondly, the qualitative approach has been applied to find factors that commercial bank officials limit to grant loans to women entrepreneurs. Survey respondents were selected on the basis of sample suitability because they offered respondents the flexibility of diversity to capture different aspects of the problems related to hurdles to credit freezing and additional procedures by financial organizations. In addition, the choice of the sample suitability was connected to the context that the researcher anticipated to survey the experience of women entrepreneurs who have real knowledge of credit and financial organizations. The main selection criterion was to have managed an SME for one year and to have applied for loans from banks, micro-credit organizations, or NGOs. Initially, one year considered as a standard for defining that applicants had wide-ranging knowledge about financial organizations. Respondents include two of the broiler farms; three of the cosmetic stores; two from goat farming; and three vegetable farms.

When designing a structured questionnaire, intensive documentary research, and an initial face to face pilot survey we get 15 respondents effective and complete response to accomplish our survey. The questionnaire contained 20 closed variables to identify the factors that hamper the access of women entrepreneurs to institutional financing. In order to quantify the opinion of women entrepreneurs, a five-point Likertscale was used for the last fifteen variables: 1 = strongly disagree, 2 = disagree, $3=$ neutral, agree $=4$, and strongly agree $=5$. One hundreds of women entrepreneurs from different parts of the country were selected for our data collection. Throughout the sampling process, we separated the whole country into four segments, such as- Southeast, Southwest, Northeast, and Northwest of Bangladesh, and from each part to guarantee illustration in every part of the country. A series of individual interviews were carried out with the designated women entrepreneurs. To examine our collected data, descriptive statistical tools (i.e. mean, standard deviation) were first used to show the relative importance of the variables. Quantitative discussions will be discussed in next. 
Table 5. Interviews performed by creditors at the exploratory stage of study

\begin{tabular}{|c|c|c|c|c|c|}
\hline $\begin{array}{l}\text { Gender and } \\
\text { Age }\end{array}$ & $\begin{array}{l}\text { Interview } \\
\text { Length } \\
\text { (Minutes) } \\
\end{array}$ & $\begin{array}{l}\text { Impact } \\
\text { of Loan }\end{array}$ & $\begin{array}{l}\text { Type of } \\
\text { entrepreneurs } \\
\text { hip }\end{array}$ & $\begin{array}{l}\text { Size of } \\
\text { Business } \\
\text { (Land/Qty.) }\end{array}$ & Remarks \\
\hline Female(39) & 60 & Positive & $\begin{array}{l}\text { Vegetables } \\
\text { Farm }\end{array}$ & 0.50 Acres & $\begin{array}{l}\text { Complicated } \\
\text { Procedure }\end{array}$ \\
\hline Male (50) & 45 & Negative & $\begin{array}{l}\text { Firming and } \\
\text { paddy } \\
\text { cultivation }\end{array}$ & 0.75 Acres & $\begin{array}{l}\text { Lack of Banking } \\
\text { Information }\end{array}$ \\
\hline Female (42) & 53 & Negative & $\begin{array}{l}\text { Fisheries \& } \\
\text { Vegetable Firm }\end{array}$ & 2.5 Acres & $\begin{array}{l}\text { High-Interest } \\
\text { Rates }\end{array}$ \\
\hline Female(41) & 50 & Positive & $\begin{array}{l}\text { Vegetables } \\
\text { Farm }\end{array}$ & 0.50 Acres & $\begin{array}{l}\text { Gender } \\
\text { Discrimination } \\
\text { Home }\end{array}$ \\
\hline Female(38) & 30 & Negative & Handy Craft & $\begin{array}{l}15 \text { Machines; } \\
22 \text { Workers }\end{array}$ & $\begin{array}{l}\text { No Bank Account } \\
\text { of Women's }\end{array}$ \\
\hline Female (34) & 34 & Negative & Handy Craft & $\begin{array}{l}11 \text { Machines; } \\
12 \text { Workers }\end{array}$ & No deposit \\
\hline Female(43) & 40 & Negative & Chicken Farm & 252 Chicken & $\begin{array}{l}\text { Complicated } \\
\text { Procedure }\end{array}$ \\
\hline Female (42) & 45 & Negative & $\begin{array}{l}\text { Customized } \\
\text { Tailor-Cloth } \\
\text { Shop } \\
\end{array}$ & $\begin{array}{l}8 \text { Machines; } \\
13 \text { Worker }\end{array}$ & $\begin{array}{l}\text { Corruption for } \\
\text { Loan Sanction }\end{array}$ \\
\hline Female(29) & 56 & Positive & Oil Shop & 2.5 Acres & $\begin{array}{l}\text { Ambiguous } \\
\text { Business Strategy }\end{array}$ \\
\hline Female(39) & 60 & Positive & Grocery Shop & 3 Shop & Lack of Collaterals \\
\hline Female(28) & 46 & Negative & Sewing Shop & 2 Shop & $\begin{array}{l}\text { It began with one } \\
\text { sewing machine } \\
\text { and increased to } \\
\text { ten later on. }\end{array}$ \\
\hline Female(51) & 27 & Negative & Land Business & 7 Acres & $\begin{array}{l}\text { Buying and selling } \\
\text { loan-accessible } \\
\text { farm land of } \\
\text { varying sizes. }\end{array}$ \\
\hline Male (40) & 48 & Negative & $\begin{array}{l}\text { Cattle Firm } \\
\text { (Meat \& Milk) }\end{array}$ & 38 Cows & $\begin{array}{l}\text { High-Interest } \\
\text { Rates }\end{array}$ \\
\hline Male (42) & 37 & Negative & $\begin{array}{l}\text { Chicken \& } \\
\text { Fisheries Farm }\end{array}$ & 300 Chickens & $\begin{array}{l}\text { lack of } \\
\text { negotiations, and } \\
\text { pitching skills }\end{array}$ \\
\hline Male (31) & 51 & Positive & $\begin{array}{l}\text { Auto rickshaw } \\
\text { Parts } \\
\text { Mechanics } \\
\text { Shop }\end{array}$ & 2 Shop & $\begin{array}{l}\text { Complicated } \\
\text { processes in } \\
\text { bureaucracy }\end{array}$ \\
\hline
\end{tabular}

Source: Author Adopted 


\section{Results and Discussions}

Table 6: Descriptive Statistics

\begin{tabular}{lcllll}
\hline Constrains & Mean & $\begin{array}{l}\text { Std. } \\
\text { Deviation }\end{array}$ & $\begin{array}{l}\text { Std. } \\
\text { Error }\end{array}$ & Skewness & Kurtosis \\
\hline Complex Loan & 1.5 & 0.595 & 0.059 & 0.735 & -0.41 \\
\hline $\begin{array}{l}\text { Initial Capital } \\
\text { Collection }\end{array}$ & 1.33 & 0.514 & 0.051 & 1.184 & 0.335 \\
\hline Business Experience & 1.47 & 0.577 & 0.058 & 0.764 & -0.395 \\
\hline Initial Training & 1.46 & 0.558 & 0.056 & 0.694 & -0.569 \\
\hline Legal Document & 1.49 & 0.502 & 0.05 & 0.041 & -2.04 \\
\hline High Interest & 1.34 & 0.572 & 0.057 & 1.483 & 1.252 \\
\hline Guarantor Problem & 1.28 & 0.473 & 0.047 & 1.284 & 0.374 \\
\hline Family Obstacle & 1.62 & 0.546 & 0.055 & 0.075 & -0.913 \\
\hline Saving Condition & 1.42 & 0.554 & 0.055 & 0.87 & -0.278 \\
\hline
\end{tabular}

Source: Author calculation

In this descriptive statistics represents the overall details of regarding women entrepreneurs in financial constraints. The mean Family Obstacle that is $\mathbf{1 . 6 2}$ and Standard deviation is 0.546 . The data appear to be skewed to the right, which explains why the mean is greater than the median.

\section{Table 7: Reliability Statistics}

\begin{tabular}{ccc}
\hline Cronbach's Alpha & Cronbach's Alpha Based on Standardized Items & N of Items \\
\hline 0.912 & 0.912 & 9 \\
\hline
\end{tabular}

Source: Author's calculation

In the reliability statistics Cronbach's Alpha is 0.912.

Table 8: KMO and Bartlett's Test

\begin{tabular}{lll}
\hline Kaiser-Meyer-Olkin Measure of Sampling Adequacy. & 0.758 \\
\hline Bartlett's Test of Sphericity & Approx. Chi-Square & 393.499 \\
\cline { 2 - 3 } & $\mathrm{df}$ & 36 \\
\cline { 2 - 3 } & Sig. & 0 \\
\hline
\end{tabular}

Source: Author's calculation

In our study, we applied the Kaiser-Meyer-Olkin Measure of Sampling Adequacy (KMO) and Bartlett's Test how adequate our sampling measurement and we found positive relevance and very satisfactory result. Usually $0<\mathrm{KMO}<1$. And if $\mathrm{KMO}>0.5$, the sample was considered adequate. Here $\mathrm{KMO}=0.758$, which indicates that the sample is adequate and we can proceed with the factor analysis. The approx. Chi-Square is 393.499 with 36 
degrees of freedom. Here, with a significance level of $95 \%, \alpha=0.05$. The $p$ value (Sig.) is $.000<0.05$, so the factor analysis is valid.

Table 9: Communalities

\begin{tabular}{lll}
\hline & Initial & Extraction \\
\hline Complex Loan & 1 & 0.693 \\
\hline Initial Capital Collection & 1 & 0.678 \\
\hline Business Experience & 1 & 0.782 \\
\hline Initial Training & 1 & 0.607 \\
\hline Legal Document & 1 & 0.846 \\
\hline High Interest & 1 & 0.712 \\
\hline Guarantor Problem & 1 & 0.829 \\
\hline Family Obstacle & 1 & 0.813 \\
\hline Saving Condition & 1 & 0.557
\end{tabular}

Extraction communalities considered for the factors in the factor solution. Small values indicate variables that do not correspond well to the factor solution and may need to be removed from the analysis. The extraction communalities for this solution are acceptable, although the lower values of Multiple Lines and Calling Card show that they do not match as well as the others.

Table 10: Total Variance Explained

\begin{tabular}{|c|c|c|c|c|c|c|c|}
\hline \multirow[t]{2}{*}{ Component } & \multirow{2}{*}{$\begin{array}{l}\text { Initial } \\
\text { Eigenvalues } \\
\text { Total }\end{array}$} & \multicolumn{3}{|c|}{$\begin{array}{l}\text { Extraction Sums of Squared } \\
\text { Loadings }\end{array}$} & \multicolumn{3}{|c|}{ Rotation Sums of Squared Loadings } \\
\hline & & $\begin{array}{l}\% \text { of } \\
\text { Variance }\end{array}$ & $\begin{array}{l}\text { Cumulative } \\
\%\end{array}$ & Total & $\begin{array}{l}\% \text { of } \\
\text { Variance }\end{array}$ & $\begin{array}{l}\text { Cumulative } \\
\%\end{array}$ & Total $\begin{array}{l}\% \text { of } \\
\text { Variance }\end{array}$ \\
\hline 1 & 4.101 & $45 \cdot 566$ & $45 \cdot 566$ & 4.101 & $45 \cdot 566$ & 45.566 & $2.69 \quad 29.886$ \\
\hline 2 & 1.264 & 14.05 & 59.616 & 1.264 & 14.05 & 59.616 & $2.651 \quad 29.458$ \\
\hline 3 & 1.151 & 12.783 & 72.399 & 1.151 & 12.783 & 72.399 & $1.175 \quad 13.055$ \\
\hline 4 & 0.672 & 7.462 & 79.861 & & & & \\
\hline 5 & 0.517 & 5.75 & 85.611 & & & & \\
\hline 6 & 0.501 & 5.566 & 91.177 & & & & \\
\hline 7 & 0.365 & 4.052 & 95.229 & & & & \\
\hline 8 & 0.277 & 3.073 & 98.303 & & & & \\
\hline 9 & 0.153 & 1.697 & 100 & & & & \\
\hline
\end{tabular}

Extraction Method: Principal Component Analysis.

In the present research the first 3 factors explain $72.399 \%$ of variance explained how financially female confronting constrains. The VARIMAX rotation tries to maximize the variance of each of the factors. 


\section{Figure 1: Scree Plot}

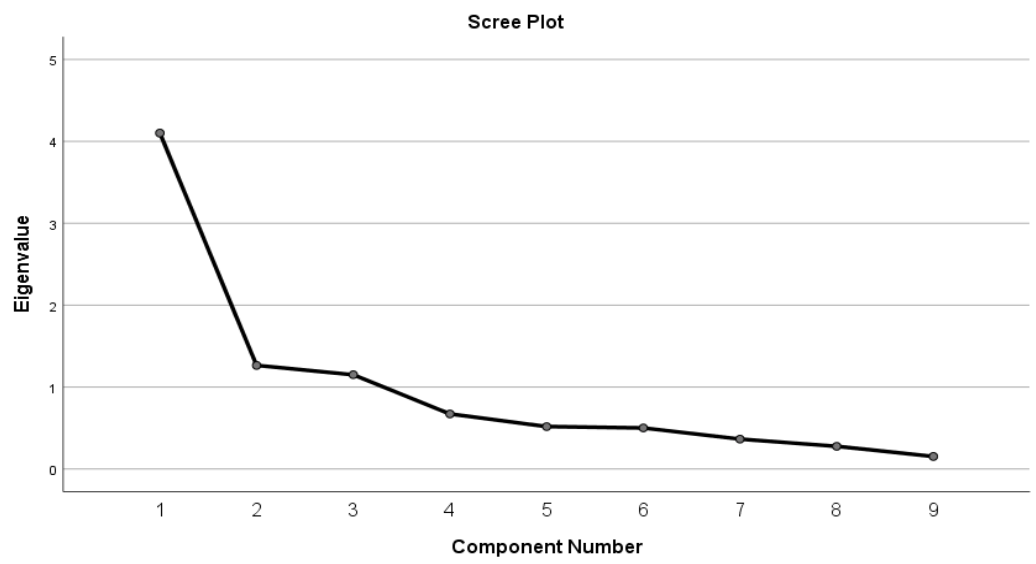

The scree plot (Kattle Criterion) graphs the Eigenvalue against the each factor on the abscissa. This graph shows that after factor 3 the total variance accounts for smaller and smaller amounts.

Table 11: Component Transformation Matrix

\begin{tabular}{llll}
\hline \multicolumn{4}{l}{ Component Transformation Matrix } \\
\hline Component & 1 & 2 & 3 \\
\hline 1 & 0.709 & 0.699 & -0.091 \\
\hline 2 & -0.699 & 0.714 & 0.044 \\
\hline 3 & 0.095 & 0.032 & 0.995 \\
\hline
\end{tabular}

Extraction Method: Principal Component Analysis. Rotation Method: Varimax with Kaiser Normalization.

\begin{tabular}{|c|c|c|c|}
\hline & \multicolumn{3}{|c|}{ Component } \\
\hline & 1 & 2 & 3 \\
\hline Complex Loan & 0.733 & -0.349 & -0.185 \\
\hline Initial Capital Collection & 0.737 & 0.144 & 0.338 \\
\hline Business Experience & 0.575 & 0.623 & -0.253 \\
\hline Initial Training & 0.652 & 0.426 & 0.023 \\
\hline Legal Document & -0.279 & 0.095 & 0.872 \\
\hline High Interest & 0.748 & -0.036 & 0.388 \\
\hline Guarantor Problem & 0.651 & -0.627 & 0.109 \\
\hline Family Obstacle & 0.875 & 0.215 & -0.023 \\
\hline Saving Condition & 0.663 & -0.321 & -0.122 \\
\hline
\end{tabular}

Extraction Method: Principal Component Analysis. A 3 components extracted. 
Table 12: Correlations

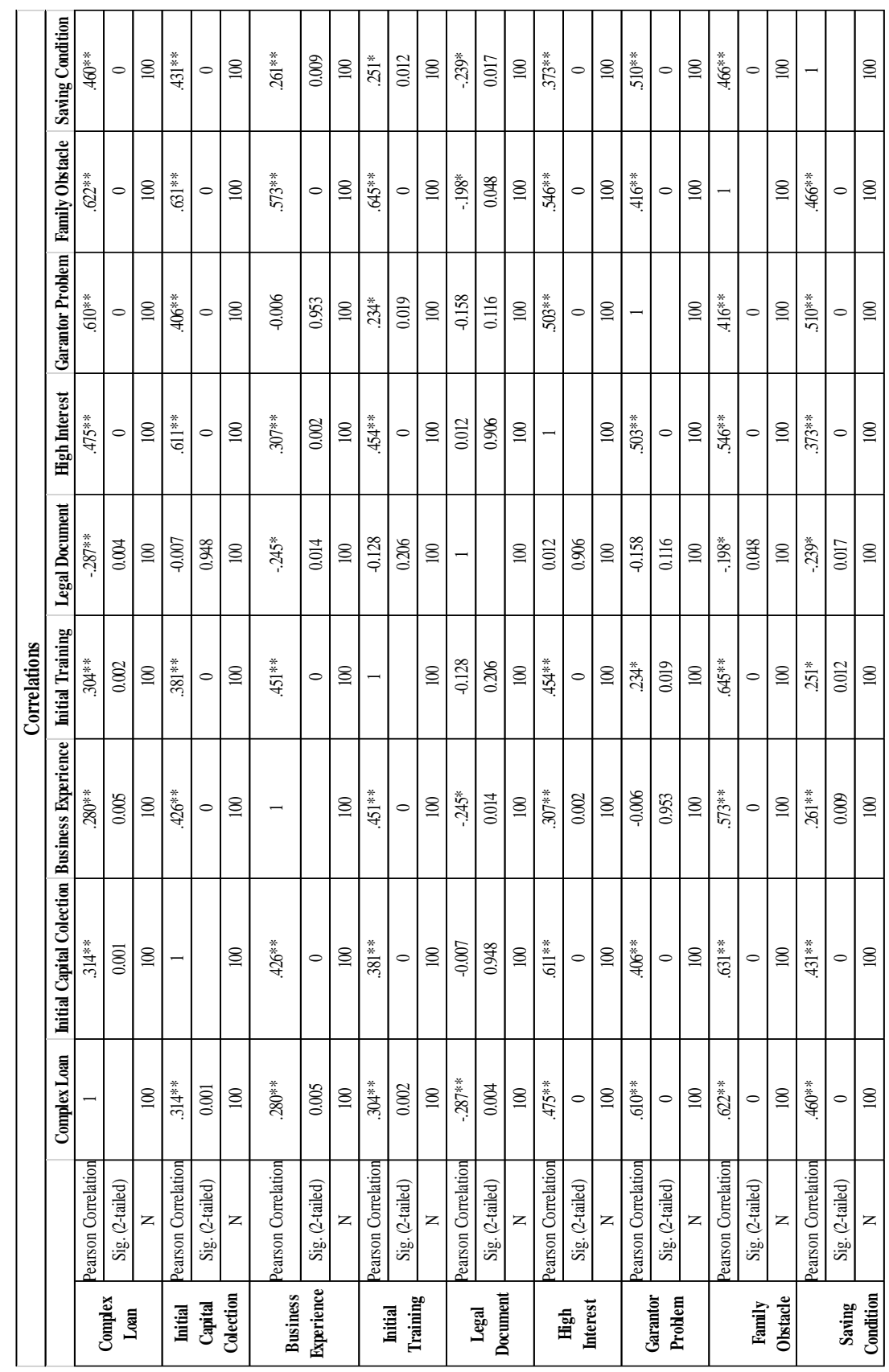

**Correlation is significant at the 0.01 level (2-tailed).

* Correlation is significant at the 0.05 level (2-tailed).

The relationships in the un-rotated factor matrix are somewhat flawless. The third factor is associated with Legal Document, the second corresponds most strongly to Business Experience, and the first factor is associated with Complex Loan, Initial Capital Collection, High Interest, and Family Obstacle. In this study, the complex loaning process and high- 
interest rate, grantor problem, and family obstacles shown in Pearson Correlation's are 0.475, 0.610, and 0.622.

The investigation additionally found that the greater expense of bank support is a snag for women entrepreneurs' visionaries in Bangladesh. All in all, the benefits of little and medium-sized organizations in Bangladesh are not high. At the point when the loan interest is high, it is hard for little and medium-sized organizations. Along these lines, the loan interest in the banks ought to be brought down. In the event that the impediments to getting and other money-related administrations from banks and different kinds of monetary associations can be expelled, women entrepreneurs' people can build up their business and improve a much commitment to the nation.

\section{Exploratory Discussions and Analysis}

\subsection{Complicated Loan Procedure}

First, following the above chart, the intricate procedure of loan disbursement has been renowned as an obstacle for women entrepreneurs in Bangladesh to get loans from banks and other financial institutions:

participants 39 years old women, Magura, Jashore, Owner of a Vegetables Farm: "I have been to banks and even some micro-credit organizations to get some loans but they wanted some documents such as registration of a business, national ID, security letter from solvent people, local chairman certificates, and even marriage certificate to prove the present marital status. This demotivated me to go again to the bank and officers in micro-finance wanted similar to banks. I am a rural woman; I do not have all these. Then I didn't manage the credits."

A participants 43 years' old women, Raozan, Chattogram, Owner of a Chicken Farm:

"Initially, I confronted many difficulties to open a bank account but after opening the account, I came to know that I have to open another account to get loans for my business! It made me down but I tried my best and got loans. But, it should not be problematic to open a bank account and get loans, because we cannot travel to the bank every day, since we have works to do at my firm."

Additional respondents also shared related information about the complicated procedure of opening bank accounts, which makes hurdles for women entrepreneurs.

\subsection{High-Interest Rates}


With regard to the accessibility of capital and credit, many participants emphasized the demand for collateral and high-interest rates as the main factors influencing their inability to access capital in the form of bank loans. The type and value of the collateral, according to participants, determined the amount of the loans received. This is expressed in the following statements:

Participants 42 years old women, Panchhat, Kishorganj, Owner of a Fisheries \& Vegetable Firm:

"If you go to the bank with land papers or house papers they are happy to give you big loans because if you don't pay the loan, they will sell the land or house to get their money. So we the women who don't have these things cannot go to the banks. If we able to manage loans which amount is insufficient to invest in our business against with high curve of interest."

Participants 47 years old man, Panchhat, Kishorganj, Firming and paddy cultivation:

"The credits proposed by banks and micro-credit organizations as well as non-governmental organizations are above expectations. I have to earn money to cover all the expenses of the business, then interest. If the interest rate is high, there is no reason in borrowing because I will fall in a pitfall."

\subsection{Insufficiency of Banking Official Information}

Several participants stated that they did not have the support of bank employees when they went to banks for loans and other services. One of the ranchers said, the participant's 50 years old man, Cloth Shop, Owner, Natore, Rajshahi

"For bank loans that I went to bank several times to open a bank account, but bank officials requested different types of documents in different time, which had a tedious task of managing them on time to obtain a loan from the bank. Although this bank has promoted its banking service, it is more flexible and transparent, but the reality is different. We want condition apply free services not trapped by hooked advertising."

Another, participant's 35years old woman, Rancher, Chandpur: "I usually had no financial knowledge of bank procedures. When I went to the reputed bank and requested help, the officials showed me a negative attitude. It could 
be my dress or face and waited for a long time. I felt scared and I come out immediately. Then I've never been to the banks. Later, I contact the local microcredit organization. They were almost the same, but I finally took some money at a very high-interest rate, which annoyed me to pay back soon."

And, the Participant's 41 years old woman, Vegetable Farming, Putia, Rajshahi:

"When I went to the bank, I had to waste my whole day, for example at 10:00 am, but I cannot finish before 3:00 $\mathrm{pm}$, there are procedures in banks and sometimes very long because I had to queue long and also walk from table to table other, what was really exhausting for me. One thing I observed, bankers feel ease and confident to provide loans to males rather than females."

The participant 54 years old man, auto-rickshaw puller owner, putia, rajshahi:
"Because I am not educated and so I feel afraid to talk with educated officials. If I do any mistake while talking to them. So, some officials provide different information about the documents required to open an account and apply for a loan. As a result, account holders and those who want to open the account face a major problem. They don't show much interest in helping us do everything well, but they seem to like making things complicated."

\subsection{Discriminations on the Basis of Gender}

For the family's wellbeing, a rural women entrepreneur intended for training from local NGOs. Her husband didn't accept it nicely and her fatherin-law didn't support much from the conservative social aspect after successfully accomplish the training, she went to the bank and tedious documentation process and grantor issues she had to face cumbersome experience but didn't eschew from her determinations and after all hurdles now she set up her own cattle firm and producing vegetables on her fertile 0.50-acre lands.

A Participant 41 Years Old Women, Magura, Jashore, and Owner of a Vegetables Farm:

"I brought up from a traditional conservative family and married a conservative religious person. I had to survive for training, bank loans, and grantor. Every sphere I had to faces inhuman torments and it's not so easy to share 
in brief. I had a concrete dream to make it effective and I did it finally. Now, I turning well off in my family and happily supporting to family and sent my children to school. Though, we are living in a digital life but still our parents' generation living in their life decades and traditional norms."

\subsection{No Bank Account of Women's}

The vast majority of rural women and women entrepreneurs do not have a bank account. Our study suggests, the result indicates that women are now more sensible and acumen than men. For family reasons such as the head of household, control, administration, customs, the priority of power, lack of confidence, education, the uncertainty of security, and distance from the financial institutions are fundamental considerations to be financially excluded from women.

\subsection{Interest Free Burn \& Disable Loan from Govt.}

Bangladesh Govt. has approved an interest-free Burn \& Disable loan. The fund was raised eighty-one crore Taka (Bangladeshi Currency) (in Bangladeshi currency) and seventy-eight crore Taka (Bangladeshi Currency) (in Bangladeshi currency) was invested in burn and disable credits. According to reports from the Ministry of Social Welfare in Bangladesh, 91,000 people benefited from this loan program. Low-income acid burning and disabled people with an average per capita annual income of at most 60,000 Taka (Bangladeshi Currency) (\$723) can take out a loan of 5,000 to 20,000 Taka (Bangladeshi Currency) (\$60-\$241). In addition, a one-time grant of 5,000 to 15,000 Taka (Bangladeshi Currency) (\$60-\$181) for an acidburned poor person.

\subsection{Corruption for Loan Sanction}

Throughout our interview, we had found several cases regarding loan sanction corruption from govt. and private credit organizations. Both stakeholders have mediators and corrupted officials who take the leveraged share from the burn \& disable people's loan.

The participants 32 years' old women, Bhurungamari, Kurigram: “While I was suffering from acid burns and after my recovery, I wanted to do something for the safe future and my family. I went to banks and microcredit office, two places where two officials told me that if he sanctioned a loan, I would have to pay 3,000 Taka (Bangladeshi Currency) (\$36), even my loan up to 60,000 (\$723), he would have to pay 5,000 Taka (Bangladeshi Currency), the loan being free of interest. “ 
Another, Participants 42 years' old woman, Cloth Shop Owner, Kishorganj

"I borrowed from the BRAC NGO. I'm physically handicapped. It was not a problem to take out the loan for the first time, but the borrower did not leave my house because I could not pay the loan installment properly and abused me. I speak a little quietly and socially I accept inferiority. I later did borrow from another local NGO. In this case, I had to take out a loan of Taka (Bangladeshi Currency) 20,000 with a bribe of Taka (Bangladeshi Currency) 3,000. Such a situation always happens at the local level."

\subsection{Ambiguous Business Strategy}

Lack of codified business strategy, proper investment \& expenditure, inefficient business plan, and poor system of serving clients considering stakeholders' inability to give loans to women micro-business. This is explained below:

A manager of the microfinance institution, Kishorganj:

"See, micro-credit provide to women is a big risk. Generally, they come up with influenced by peer group and undefined business goals where fulfill to their customer desire is at high risk. In this circumstance, this makes it very difficult to grant a loan to these women. So the only thing we do is to use their savings as collateral to give them a little loan we think they deserve."

\subsection{Loan Has Given Positive Changes of Life}

A frequently asked question to almost all of the borrowers was, "Is the loan working for you?" Other questions were, "What else do you think is necessary to be a successful entrepreneur in addition to the loan?" And "When it comes to starting a new business, is the loan enough?" One of the interviewees, who had almost 18 years of experience in taking out loans at BRAC Bank, replied that she had become completely self-sufficient. Now his small business has become productive and has supported his household income, and his finances are in good shape:

Participants 39 years' old women, Grocery Shop Owner, Raozan, Chattogram:

"This loan has increased my household income at a good pace. On the one hand, this loan paved the way for income and, on the other hand, it increased my wealth. 
Not only l, but many of the women in the neighborhood have had great success in increasing their household income through this loan."

\subsection{Loan Invest in Unproductive Way}

To maintain the relevant of our study we heard from both stakeholder's opinions to figure out the real facts, so one of the mid-level bank official claimed that

A participants 42 years old man, Branch Manager, Agrani Bank, Dhaka:

"The most of the cases applicants apply for SME loan but they utilize this loan for unproductive way and several times we investigate to ensure legitimate use of loaning money. We have to keep up a track record and how many borrower changes their life by taking this financial benefits and our prime motto equally include into everyone in our financial frameworks. Recently, we experienced a few cases, credit candidates applying loans beyond their needs and they couldn't show a sensible records and answer."

\subsection{Complicated Processes in Bureaucracy and Consolidated Remarks}

Starting a production plant requires a set of permits, Registrations and liquidations. For instance, starting an SME requires: 1. Business license granted by the local authority; Agency of Government (Chairman of UP, City Corporation Office), (2) registration of a trademark by the Office of the Register of Trademarks Register of Patents, Designs and Trademarks under the Ministry of Finance (3) Amount of Tax Identification Number (TIN) NBR, or Ministry of Finance Income Tax Agency, (4) Declaration of value added tax (VAT) from the same registration. Authority, (5) Membership in any business body (district authority) Chamber or Sectorial Association), (6) Registration of import certificate from Ministry of Commerce (7) Environment Clearance by the Ministry of the Environment, (h) Clearance of Fire Bridget approval, among many more. It is not so easy to complete all these formalities. The desk wants a bribe to move the file properly (Abdin, 2010).

\section{Policy Recommendations}

\section{A. The government and decision makers should ensure that:}

- The primary beneficiaries of schemes under the financial inclusion agenda are women.

- Via financial literacy initiatives, women are conscious of the frameworks and services. 
- Monitoring from the grassroots to ensure the successful execution of the policies.

- The regulatory system is useful and functions to the advantage of woman entrepreneurs (e.g. credit scheme policy, reports, financial collaterals etc.)

- Need to assure the equal rights for everyone.

- Eliminate bureaucracy process and make it flexible and business friendly ambient equally.

\section{B. Banks and Financial Institutions in the Private Sector need}

- To explore an alliance with capacity-building projects (including addressing whole value chains) to better connect access to finance.

- Strengthen knowledge management frameworks to integrate new, tailor-made financial goods and services for woman entrepreneurs.

- Have collateral-free loans and the setting of lending targets for woman entrepreneurs and a zero collateral lending guarantee system.

- Identify frameworks for the support program for women entrepreneurs that can influence the whole supply chains where women entrepreneurs are based.

\section{Administrative and Legislative}

- The legislative mechanisms for women's trade licenses can be facilitated by city corporations, counties and state councils.

- The government should grant woman entrepreneurs special tariff facilities.

- Providing woman entrepreneurs with logistical assistance and facilities for dissemination of information on taxes, licenses and VAT and simplification of those regulations.

D. Monitoring and Implementation of Current Policy

- Increase public-private partnership and collaboration between the government and NGOs to enhance the coverage of the scheme for credit and preparation.

- Bangladesh Bank should set a target for the issuance of loans to women SMEs by each bank and create a monitoring team to track the execution of the circular.

- Establish a SME cell in each private bank and promote the process of securing loans and opening women's accounts.

- The prospect of receiving institutional loans should be readily available in both rural and urban areas.

\section{E. The Women Friendly Programs}


- In order to reserve space for woman entrepreneurs in the underlying industries, city corporations and municipalities may have special quotas.

- The media should play a critical role in disseminating the knowledge and services required for women's SMEs and other disadvantaged communities.

- Organize trade fairs, especially for women entrepreneurs, in those countries where Bangladeshi products are in high demand.

\section{F. E-Commerce}

E-commerce has proven to be an exciting option to connect entrepreneurs directly with their buyers or to improve the ease of procurement of raw materials. This alternative helps woman in particular, who often lack mobility, to ramp up business without upsetting social norms.

- Mobile phone-based information campaigns should be low-cost and ensure administrative feasibility.

- Multi-stakeholder collaboration and expertise and information will promote greater access of community entrepreneurship.

\section{Conclusion}

Female entrepreneurship is not only a source of income, but also a means to achieve financial independence. Women who are involved in business are better than women who are not. The Government of Bangladesh recognizes the importance of female entrepreneurship and has taken several initiatives to encourage women to participate in various micro, small and medium sized enterprises. At the same time, banks, financial institutions and financial institutions have also attached importance to the development of women entrepreneurs in Bangladesh. These financial intermediaries provide loans to SMEs, especially women entrepreneurs, in accordance with the guidelines of the Bank of Bangladesh. This study linkage with rural women entrepreneurs and financial constraints, and how women can contribute to the mainstreamed economy focused on several factors which influencing into the informal economy of rural Bangladesh. This inquiry found that a variety of institutional, personal, and contextual factors that influenced and hampered women's entrepreneurship and financial exclusions. Bangladesh is considering the $7^{\text {th }}$ fastest growing economy in the world and achieved 29th position by purchasing power parity and the development of women entrepreneurs would have a very positive impact on the broad-spectrum business prospects in this country in the informal economy. This study identifies some significant obstacles, which is why women entrepreneurs should offer 
all possible benefits in removing the hurdles ((Esayas \& Tolossa, 2015; Connerley \& Wu, 2016; IMF). Our inquiry supported this study where they recommended to remove barriers for women and proposed not an individual endorsement (Nawaz, 2012; Baporikar, et al, 2016; Jannuzi \& Peach, 2019). The current government is unremittingly advising banks to simplify the credit process. Thus, the existence of this barrier is certainly terrifying for the respective policymakers. Moreover, technological developments, particularly among private, commercial and public banks in Bangladesh, are expected to reduce the complexity of the loan payment process Owing to technological developments, mainly private, commercial and public banks in Bangladesh are anticipated to lessen the intricacy of the loan payment process (Hasan et al., 2016). Thus, this study could provide a source for senior government officials, as well as senior banking authorities, to take the right initiatives to reduce complex credit processes and suggesting to implement necessary sustainable policy to ensure women can be included by financially and bring changes in their lives. This research is also an essential contribution to justify the need to reduce interest rates. If the interest rate is lowered, the number of entrepreneurs can increase and existing SMEs can borrow.

\section{References}

Abidin, J. M. (2017). SMEs and our development goals. The Daily Star.

Abdin MJ (2010). Bangladesh's SMEs facing so many challenges, the independent.

Afrin, S., Islam, N., Ahmed, S. \& Ahmed, Shahid (2010). Micro Credit and Rural Women Entrepreneurship Development in Bangladesh: A Multivariate Model. Journal of Business and Management, Vol. 16, No. 1.

Alam CM, Miyagi K (2004). An approachable analysis of microenterprise in Bangladesh, working paper Series No.8, Department of International Studies, Hagi International University, Japan.

Alam MS, Ullah MA (2006). SMEs in Bangladesh and Their Financing: An Analysis and Some Recommendations, the Cost and Management. 34(3): 57-72

Bamfo, B. A., \& Asiedu-Appiah, F. (2012). Investigating the Challenges and Prospects of Female Entrepreneurs in Ghana. International Journal of Business and Management Studies, 1(1), 43-54.

Biekpe, N. (2004). Financing small businesses in sub-Saharan Africa: Review of some key credit lending models and impact of venture capital provision. Journal of African Business, 5(1), 29-44.

BIS. (2015). Payment Aspects of Financial Inclusion. September 2015.

Boateng, S., \& Poku, K. O. (2019). Accessing finance among women-owned small businesses: Evidence from lower Manya Krobo municipality, Ghana. Journal of Global Entrepreneurship Research, 9(5). 
Collingridge, D. S. (2013). A Primer on Quantitized Data Analysis and Permutation Testing. Journal of Mixed Methods Research, 7(1), 81-97.

Connerley, M. L., \& Wu, J. (2016). Handbook on well-being of working women. London: Springer.

Chowdhury, M., Alam, Z. and Arif, I. (2013). Success factors of entrepreneurs of small and Medium sized enterprises: evidence from Bangladesh. Macro Think Institute. Vol. 3 (2).

De Vita, L., Mari, M., \& Poggesi, S. (2014). Women entrepreneurs in and from developing Countries: Evidences from the literature. European Management Journal, 32(3), 451-460.

Esayas, B., \& Tolossa, D. (2015). Women's Economic Empowerment, Obstacles for Success: Experiences from Southern Ethiopia. American Journal of Entrepreneurship, 8(2).

Ghosh, P. K., Ghosh, S. K., \& Chowdhury, S. (2017). Factors hindering women entrepreneurs' access to institutional finance- an empirical study. Journal of Small Business \& Entrepreneurship.30 (4), 279-291.

GPFI (2011). Global Partnership for Financial Inclusion. G20 Leadership Summit, Cannes, November 5th, 2011.

Hussain et al., (2019). Does financial inclusion increase financial resilience? Evidence from Bangladesh. Journal Development in Practice.

International Labor Office (2002b). Women and Men in the Informal Economy: A Statistical Picture. Geneva: International Labor Office.

Islam \& Jantan (2017). The Glass Ceiling: Career Barriers for Female Employees in the Ready Made Garments (RMG) Industry of Bangladesh. Academy of Strategic Management Journal. 16(3).

Islam, Md. Sabit Bin \& Mukit, Mohammad Mushfiqul Haque (2019). Globalization: Blessing or Curse for the Economy of the Developing Countries? International Journal of Science and Business (IJSAB), 3(1), 29-36.

International Monetary Fund (IMF) (2015). Financial Inclusion: Can It Meet Multiple Macroeconomic Goals? September 2015. SDN/15/17.

Jannuzi, F. T., \& Peach, J. T. (2019). The agrarian structure of Bangladesh: An impediment to Development. Routledge.

Jahed, M., U. Kulsum, and S. Akhtar. (2011). Women Entrepreneurship in Bangladesh: A Study On Support Services. Journal of Global Management Review. 5 (3): 2-14.

Kelley, D., Bosma, N. S. \& Amorós, J. E. (2011). Global Entrepreneurship Monitor 2010 Executive Report.

Khalily, M. A., et al. (2014). Access to Financial Services in Bangladesh. Institute of Microfinance. Dhaka.

Khalily, M.A. (2016). Financial Inclusion, Financial Regulation, and Education in Bangladesh (December 7, 2016). ADBI Working Paper No. 621.

Lader, P. (1996). The Public/Private Partnership. Springs. Spring, 35(2), 41-44.

Makena et al., (2014). Challenges facing women entrepreneurs in accessing business Finance in Kenya: Case of Ruiru Township, Kiambu County. IOSR Journal of Business and Management (IOSR-JBM).

Mohanty, S. K. (2009). Fundamentals of Entrepreneurship. New Delhi: PHI Learning. Momsen, Janet. (2010). Gender and Development. Routledge. New York, New York. 
MIFA (2009). Bangladesh Microfinance and financial sector diagnostic study, Final report, 2008. MIFA- promoting microfinance in Asia, IFC, Washington Dc, USA

Mukit, Mohammad Mushfiqul Haque \& Islam, Md. Sabit Bin. (2018). The emergent impact of internet banking espousal in Bangladesh: opportunity \& hitch. International Journal of Innovative Science and Research Technology (IJISRT), 12(3), 535-539.

Nawaz, F. (2012). Problems of Woman Entrepreneurship Development in Bangladesh: A Case Study of Rakub. Pertanika. Journal of Social Science and Humanities. 20(3), 601-614.

Oxfam (2020). Why the majority of the world's poor are women?

Rahman, A. (2009). Financial inclusion as a tool for combating poverty - the Bangladesh Approach. A keynote address in 1st AFI Global Policy Forum. Nairobi.

Reynolds, P, WD Bygrave, E Autio and M Hay (2002). Global Entrepreneurship Monitor: 2002 Executive Monitor. London: London Business School.

Riyadh, A. N., Bunker, D. \& Rabhi, F. (2010). Barriers to e-finance adoption in small and medium Sized enterprises (SMEs) in Bangladesh.

Sarma, Mandira (2012). Index of Financial Inclusion A measure of financial sector Working Papers on Money, Finance, Trade and Development. Working Paper no. $07 / 2012$.

Warnecke, T. (2012). Female Entrepreneurship in China: Opportunity- or NecessityBased? Student-Faculty Collaborative Research Publications 23, 23(1).

World Bank (2019). SME Publications. 